\title{
AUDIT COMMITTEE DISCLOSURE TONE AND EARNINGS MANAGEMENT
}

\author{
Habiba Al-Shaer \\ Newcastle University \\ Business School \\ 5 Barrack Road \\ Newcastle upon Tyne, NE1 4SE, UK. \\ Email: habiba.al-shaer@ncl.ac.uk
}

\author{
Mahbub Zaman* \\ Hull University \\ Business School \\ Cottingham Road \\ Hull, HU6 7RX, UK. \\ Email: $\underline{\text { m.zaman@hull.ac.uk }}$
}

Accepted Version: 15 th April 2021

*Corresponding author: Professor Mahbub Zaman, Hull University, Business School, Cottingham Road, Hull, HU6 7RX, UK. Email: m.zaman@hull.ac.uk

Acknowledgements: The authors would like to thank the editor and two anonymous reviewers for the constructive comments and suggestions on earlier draft of this paper.

This is the accepted version of the paper and has not been journal proofread. Please cite as follows: Al-Shaer, H \& Zaman, M. (2021). Audit committee disclosure tone and earnings management. Journal of Applied Accounting Research, forthcoming. 


\title{
AUDIT COMMITTEE DISCLOSURE TONE AND EARNINGS MANAGEMENT
}

\author{
Version: 15th April 2021
}

\section{STRUCTURED ABSTRACT}

\section{Purpose:}

This paper examines the effect of audit committee reporting, measured by the tone of audit committee disclosures, in improving financial reporting quality as proxied by earnings management.

\section{Design / Methods}

We focus on the textual properties of $\mathrm{AC}$ reports, particularly the tone of $\mathrm{AC}$ disclosure, and their impact on financial reporting quality proxied using real and accruals-based earnings management. For additional analysis, we use a financial reporting index and matched sample. Our analysis is based on a sample of UK FTSE 350 firms.

\section{Findings:}

Our analysis suggests that audit committee reports are not boilerplate but varied in language. We find audit committee reporting is negatively associated with both real and accruals-based earnings management. In our additional tests, we find a positive association between financial reporting quality index and reporting tone.

\section{Originality / value:}

Though the importance of AC disclosures in improving reporting quality is well recognised in policy guidelines and governance recommendations, no study has employed computer-based textual analysis of AC reports and investigated the effect of $\mathrm{AC}$ disclosure tone and the role it can play in achieving higher reporting quality.

\section{Research Implications:}

Overall, our paper provides baseline evidence for future research and policy making and reveals that ACs reporting what they have done increases transparency and impacts on reporting quality.

Keywords: audit committees; voluntary disclosure; earnings management; textual analysis. 


\section{INTRODUCTION}

Corporate governance can affect the quality of financial reporting. While there is evidence to suggest that governance structures reduce earnings management, there is limited evidence on how audit committee $(\mathrm{AC})$ reporting affects financial reporting quality. Guidelines on AC role and responsibilities in the UK require ACs to report on significant issues considered in relation to financial reports and auditing (FRC, 2012). This paper focuses on the textual properties of AC reports, particularly the tone of AC disclosures, and examines the effect of $\mathrm{AC}$ reporting in improving financial reporting quality as proxied by earnings management.

Recognizing that reporting by ACs in relation to their activities may impact on the quality of financial reporting, we draw on the literature on textual properties and focus on the tone of AC reports. Our paper extends the literature which has mainly investigated the relationship between ACs characteristics and financial reporting quality. For example, studies show that AC expertise enhances earnings quality (Beasley et al., 2009; Bedard and Gendron, 2010; Cohen et al., 2013). A number of studies finds a positive association between AC size and the quality of financial reporting (e.g., Mangena and Pike, 2005; Li et al., 2012; Mangena and Tauringana, 2008). Moreover, previous research has established the importance of active AC oversight of the financial reporting process for improving the quality reporting (Beasley et al., 2009; Zaman et al., 2011). Our paper also complements qualitative studies, mainly based on interviews with AC participants in small number of companies, on the $\mathrm{AC}$ process showing that $\mathrm{AC}$ actions play a key role in configuring meanings of effectiveness (Gendron and Bédard, 2006; Turley and Zaman, 2007; Beasley et al., 2009; Compernolle, 2018; Khemakhem and Fontaine, 2019). It also adds 
to the literature on AC disclosures (e.g., Guttierrez et al., 2018; Lennox et al., 2018 and Czerney et al., 2019; Sahyoun and Magnan, 2020) through a focus on the textual properties of $\mathrm{AC}$ reports, particularly the tone of $\mathrm{AC}$ disclosures, and examining the effects on financial reporting quality as proxied by earnings management.

Our analyses based on a sample of UK FTSE 350 firms support our hypothesis that the tone of AC report disclosures is negatively associated with earnings management and suggest the tone of AC disclosures, as expressed in the choice of words used in describing $\mathrm{AC}$ engagement, conveys information that affects the communication function of AC reporting thereby improving reporting quality. Our analysis indicates that $\mathrm{AC}$ reports are not boilerplate but varied in language choice which contributes to improving financial reporting quality. Moreover, our findings also hold when we control for endogeneity. When we use alternative proxies for financial reporting quality, we find that $\mathrm{AC}$ disclosure tone has a significant and negative association with accrual-based earnings and a positive and significant association with the financial reporting quality index.

In contrast to the predominant focus in existing studies on the US setting, our study is based on the UK context. The UK provides a meaningful and useful context for our study. First, as noted by Ghafran and O'Sullivan (2013), evidence on the financial reporting effects of ACs in the UK setting is quite limited. Key exceptions include: Peasnell et al. (2005), Mangena and Pike (2005), Mangena and Tauringana (2008) and Li et al. (2012). Second, compared to US regulations on corporate governance which are relatively rigid, the Financial Reporting Council (FRC) in the UK adopts a softer, comply or explain regulatory approach (FRC, 2012b). Third, the higher risk of litigation can inhibit the management of US firms from making detailed 
voluntary disclosures about governance practices (Francis et al., 1994; Baginski et al., 2002). Whereas, under the UK's flexible governance environment, risk of litigation from shareholders or other stakeholders is relatively low (Clatworthy and Jones, 2003; Black et al., 2005).

Though the importance of $\mathrm{AC}$ disclosures in improving reporting quality is well recognised in policy guidelines and governance recommendations, to the best of our knowledge, no study has employed computer-based textual analysis of AC reports and investigated the effect of $\mathrm{AC}$ disclosure tone and the role it can play in achieving higher reporting quality. Overall, our paper provides baseline evidence for future research and policy making and reveals that ACs reporting what they have done increases transparency and impacts on reporting quality.

The reminder of the paper is structured as follows. Section 2 summarizes prior literature. Section 3 develops the hypothesis. Section 4 describes the research method including model specification, variable measurement, and the sample. Section 5 presents the findings while in section 6 we provide a summary and conclusion.

\section{LITERATURE REVIEW}

The theoretical underpinning for ACs is based on agency theory which leads to an expectation that effective ACs will enhance governance and the quality of financial reporting and auditing (Turley and Zaman 2007; Ghafran and O'Sullivan, 2017). Beasley et al. (2009) argue that agency theory is relevant in enhancing our understanding of the role of governance in the audit process since the audit is focused on financial reporting and internal control. Agency theory suggests that factors that create the need for closer monitoring of management produce the need for effective 
ACs (Collier and Zaman, 2005; Turley and Zaman, 2007; Zhou et al., 2018). From an agency perspective firms with high information asymmetry and agency costs will be inclined to reduce such costs by providing substantive oversight and disclosure relating to governance (Piot and Janin, 2007). Earnings management intended to mislead stakeholders about the underlying economic performance of the firm can compromise reporting quality. A primary purpose of ACs is thus to constrain earnings management. Overall, prior research suggests that ACs are associated with improved financial reporting (Zaman et al., 2011; Ghafran and O'Sullivan, 2013; Badolato et al., 2014; Khemakhem and Fontaine, 2019). ACs reporting publicly on significant issues considered in relation to financial reporting and auditing, and how these issues have been addressed can increase the transparency of their monitoring. Moreover, it may also intensify AC substantive oversight and thereby improve quality of reporting.

A focus on $\mathrm{AC}$ reporting enables us to respond to the call for more research, inter-alia, by Beasley et al. (2009: p113): “of particular importance is whether variations in process are associated with variations in financial reporting and governance outcomes, above and beyond previously documented relations between AC characteristics and financial reporting outcomes". Our focus also resonates with reviews of AC literature by Bedard and Gendron (2010) as well as Broye and Johannes (2021) who suggest that despite the existing literature focusing on AC characteristics, our understanding of their effects is still limited and call for more research that helps to increase understanding of ACs. McNulty et al. (2013) also argue that examining AC attributes alone fails to capture what really goes on in ACs. Our focus on AC reporting thus complements research largely focused on AC attributes. 


\section{HYPOTHESIS DEVELOPMENT}

Research on textual analysis of corporate disclosures focuses on textual analysis of the readability and tone dimensions of annual reports (see Li, 2008; Lehavy et al., 2011; Loughran and McDonald, 2014; Ajina et al., 2016). Several studies examine whether companies use tone in qualitative disclosures to convey fundamental information. Bicudo de Castro et al. (2019) find that annual reports that convey positive tone are associated with lower audit fees. Davis et al. (2012) find that the increase in tone optimism of earnings press releases leads to an immediate stock price response to earnings announcement and Davis and Tama-Sweet (2012) argue that managers have incentives to use tone strategically in their qualitative disclosures and find that tone pessimism predicts poor future performance. Huang et al. (2013) find that abnormal positive tone misleads investors and reveals managerial incentives to misinform investors about future performance. Bassyouni et al. (2020) report that firms with high level of board independence have less positive tone in their narrative reporting.

Some recent auditing literature focuses on changes in auditors' reports and their informativeness. Textual analysis of audit reports is however limited and at an early stage. Gutierrez et al. (2018) investigate the UK requirement to expand auditors' reports and find that mere increase in disclosures is not associated with increase in audit fees or informativeness. Similarly, Lennox et al. (2018) examine the informativeness of new reporting standards in UK that require auditors to disclose the risks of material misstatements and find these disclosures lack incremental information content, suggesting that the expanded audit reports do not provide investors with additional value-relevant information. In contrast to Gutierrez et al. (2018) and Lennox et al. (2018), Reid et al. (2019) examine the impact of UK's auditor 
reporting changes on financial reporting quality and find that the new auditor reporting requirements are associated with a significant improvement in financial reporting quality. Czerney et al. (2019) examine the explanatory language added to unqualified audit reports and how investors respond to such language. They find that investors generally do not respond to explanatory language at the time of the audit report release. Sahyoun and Magnan (2020) analyse AC disclosures based on recommendations from multiple industry and governance organisations' reports and its association with banks' earnings management and find that the voluntary disclosures in AC reports are used as a tool for impression management.

There is scarcity of research focusing on the textual analysis of AC reports. We are able to identify one unpublished article that focuses on the textual analysis of AC reports. Draeger et al. (2019) undertake textual analysis of US firms' AC reports and find that AC reports have become shorter over time and include fewer voluntary disclosures. The study finds no evidence that AC characteristics are associated with the level of disclosure in AC reports. Draeger et al. (2019) argue that AC reports typically use boilerplate language and present limited information on AC oversight of the external auditor.

Samaha et al. (2015) in their review note that audit committees play a pivotal role by improving the quality of information disclosed. To the best of our knowledge, no previous study has examined the tone of $\mathrm{AC}$ reports and their impact on financial reporting quality. The language used in $\mathrm{AC}$ reports can give an insight into the nature of communication to the user (Coram et al., 2011). For example, if there is additional disclosure relating to risks of material restatements or going concern risk, the tone of information disclosed in AC reports is likely to be negatively affected. The linguistic 
content of the corporate reports (including AC reports) is helpful in explaining firms' reporting quality (Loughran and McDonald, 2011). Therefore, we expect AC disclosure tone that conveys information which enhances users' understanding of the audit process will affect the communication function of AC reporting and increase the transparency of AC monitoring and thereby improve financial reporting quality as proxied by earnings management.

Overall, the tone of AC reporting is important because ACs help to create and maintain a reporting system and environment within firms that supports the integrity of the financial reporting process. AC disclosure tone can signal their attention and sharpen their focus on certain financial reporting items such as accounting adjustments and revenue recognition. AC disclosures with constrain tone to accounting figures (e.g., revenues recognition) can help increase reporting quality through lower earnings management. Moreover, AC disclosures with litigious tone relating to accounting entries (e.g., recording a provision) may help increase overall earnings quality. Our hypothesis is:

Hypothesis. The tone of audit committee report disclosure is negatively associated with earnings management.

\section{RESEARCH METHODS}

\subsection{Sample and Data}

The sample for our study consists of FTSE 350 companies listed on the London Stock Exchange (LSE) during 2013 and 2014. The FTSE 350 represents highest market capitalization and are the centre of attention for investors, regulators and professional bodies. The time period is appropriate for the study as the $\mathrm{AC}$ reporting patterns over the period of two years since the issuance of the FRC's revised guidelines for ACs 
published in 2010 means sufficient time has lapsed for companies to achieve compliance. ${ }^{1}$ Financial data is collected from annual reports and DataStream. We remove financial firms and companies operating in the utility industry because these firms have unique regulatory environment. We also loose a few observations due to missing data for some of the financial variables. Table 1 shows how our sample which begins with 700 firm-years and ends with a final sample of 540 firm-years.

\section{[Table 1 about here]}

\subsection{Earnings Management Measures}

Following prior studies our main proxy of earnings management is the real earnings management metrics $\left(E M \_R M\right)$. To capture the total effects of real earnings management, we follow Cohen and Zarowin (2010) and use an aggregate measure of real earnings management calculated as the sum of abnormal discretionary expenses multiplied by negative one (so that the higher amount, the more likely it is that the firm is cutting discretionary expenses) and abnormal production costs (increasing production to spread the fixed costs of production over a large number of units). ${ }^{2}$ (See untabulated Appendix 1 for detailed calculations of earnings management metrics). Following Cheng et al. (2016), we also use the performance-matched real earnings management (EM_PRM) as a proxy for financial reporting quality, where real earnings management is adjusted for the performance of a matched firm.

\footnotetext{
1 The FRC revised guidelines recommend that the core functions of audit committees are expressed in terms of 'oversight', 'assessment' and 'review' of a particular function (FRC, 2010).

2 In untabulated analysis we include an aggregate measure of real earnings management that is equal to the sum of abnormal cash flows and abnormal discretionary expenses, both multiplied by negative one (so that the higher the values the more likely the firm is accelerating sales using aggressive price discounts and/or lenient credit terms and reducing the amount of discretionary expenses). Our inferences are qualitatively similar to those reported when we use this alternative measure, and therefore, for parsimony, we report the results using one aggregate measure of REM.
} 
Additionally, we use the accrual-based earnings as an alternative measure of financial reporting quality. Prior studies often rely on the Jones Model (Jones, 1991) or the modified Jones Model (Dechow et al., 1995) to calculate accrual-based earnings. We use the modified Jones Model to measure the accrual-based earnings (EM_MJM) (untabulated Appendix 1). ${ }^{3}$ Prior research on accruals-based earnings suggests that discretionary accrual models might be misspecified when applied to firms with extreme financial performance (e.g., Dechow et al., 1995; Kothari et al., 2005). The discretionary accrual measure is also adjusted for the accrual performance of a matched firm where matching is on the basis of return on assets and industry. Following Kothari et al. (2005) we also estimate performance-matched earnings management proxy $\left(E M \_P E M\right) .{ }^{4}$ Finally, we compute an index (FRQ_index) as an additional proxy by taking the standardised averages of EM proxies used in this study, i.e., EM_RM, EM_PRM, EM_MJM, and EM_PEM and multiply them by minus one so that it is increasing with reporting quality. ${ }^{5}$

\subsection{AC Reporting Tone}

In measuring the disclosure tone of $\mathrm{AC}$ reports we draw on prior literature that has focused on the textual analysis of financial reports. ${ }^{6}$ Various methods have been used

\footnotetext{
3 Owens et al. (2017) show how idiosyncratic shocks to firms' operating environments can generate through several years of financial statements and reduce discretionary accrual models' goodness-of-fit, therefore, creating accrual model misspecification. They state "missing from accrual models are the underlying economic circumstances that give rise to firm performance. These circumstances often vary widely across firms and over time, resulting in different levels of expected accruals that the accrual models, by construction, do not capture." (Owen et al., 2017, p.184). We use a sample of companies over a two-year period, hence due to data limitation, it is less likely that idiosyncratic shocks will impact on our accrual model.

4 We also address the concern that firm growth may affect the discretionary accrual measure (Collins et al., 2016) by adjusting for sales growth. Our main results are unaffected when we make this adjustment.

5 Similar to Biddle et al. (2009) we also estimate a principal-component analysis (PCA) in Stata software by taking the proxies of earnings management used in this study. The factor solution consists of two factors with eigenvalue larger than one (1.22). We multiply the PCA estimate by negative one so that it is increasing in reporting quality (untabulated).

6 There is growing empirical research in accounting and finance using textual analysis of qualitative information. The disclosure channels used in the literature include annual reports/10-K/10-Q fillings (Li, 2008, 2010; Miller,
} 
to measure qualitative disclosures, such as the naïve Bayesian machine-learning algorithm (Li, 2010), General Inquirer and Diction (Tetlock, 2007; Tetlock et al., 2008; Kothari et al., 2009), and Linguistic Inquiry and Word Count (LIWC) (Li, 2008; Draeger et al., 2019; Smith, 2019). These methods are based on using word dictionaries that have been transferred from the field of social psychology into the finance context (Kang et al., 2018). Loughran and McDonald (2011) argue that these psychological dictionaries are not suitable for financial disclosures and suggest the use of financialcustomised word list to better reflect the finance context. The authors created financebased word lists to describe the negative, positive, litigation, constrain, strong and weak tones in financial disclosures.

Prior research on corporate disclosure has used various textual analysis measures to investigate the text-based information released by firms including readability (Li, 2008; Ajina et al., 2016; Kim et al., 2017; Lo et al., 2017; Luo et al., 2018), positive vs. negative tone (Davis et al., 2012), and aggregate tone (Huang et al., 2013; Kang et al., 2018). Kang et al. (2018) argue that when investors read financial reports and make investment decisions, they consider good and bad events alike. Therefore, separating the effects of positive and negative text-based information is more likely to lead to mixed findings. Purda and Skillicorn (2015) argue that linguistic analysis can be used effectively to detect unusual discrepancies in financial reporting. Their study uses language-based technique including the litigious and negative words lists form Loughran and McDonald (2011) as a tool for corporate fraud detection. Moreover, Bodnaruk et al. (2015) use textual analysis to measure the extent to which a firm is

2010, You and Zhang, 2009; Ertugrul et al., 2017; Kang et al., 2018), earnings press release (Davis et al., 2012; Davis and Tama-Sweet, 2012; Huang et al., 2013), media news (Tetlock, 2007; Tetlock et al., 2008), management discussion and analysis section of the annual report (Lo et al., 2017), and conference calls (Larcker and Zakolyukina, 2012). 
financially constrained and create a constraining word list similar to the one used in Loughran and McDonald (2011). The study argues that companies facing financial challenges are more likely to use constraining tone in their $10-\mathrm{K}$ fillings to communicate their concerns to shareholders, thereby reducing litigation exposure.

We proxy for $\mathrm{AC}$ tone using three alternative measures: $A C T \_$Litigious, $A C T_{-}$Constrain and $A C T \_L I W C$. We use the litigation and constrain word dictionaries created by Loughran and McDonald (2011) in our main tests similar to Bodnaruk et al. (2015) and Purda and Skillicorn (2015). ${ }^{7}$ Thus, we include ACT_Litigious measured by the word count frequency in the AC report based on the Loughran and McDonald Litigious Word List, ACT_Constrain is measured by the word count frequency in the AC report based on the Loughran and McDonald Constrain Word List. ${ }^{8}$ Also, similar to Kang et al. (2018), we define the tone as the frequency difference between the numbers of positive and negative words divided by the total word count using LIWC custom dictionary of positive and negative word lists. ${ }^{9}$

\subsection{Control Variables}

In testing our models, we control for AC, boards of directors and firm characteristics. We use ACStrength, similar to Zaman et al. (2011), to measure the strength of an AC computed by totalling the proxies of five AC characteristics. We measure the components using dummy industry-adjusted variables to enable the calculation of the composite measure of AC strength. Accordingly, all variables are defined in Table 1.

\footnotetext{
7 We do not use Loughran and McDonald's weak and strong word dictionaries due to low rates of occurrences in our sample.

${ }^{8}$ Loughran and McDonald's dictionary has 903 words included in the Litigious word list and 184 words included in the Constrain word list.

${ }^{9}$ We also calculate the tone based on Loughran and McDonald's word list of positive and negative words. Our main results are unaffected (untabulated).
} 
Similar to our measurement of AC strength, we use a composite measure for the strength of the corporate board, i.e., BODStrength computed by totalling the proxies of six board characteristics.

Prior studies find firm-specific characteristics can affect earnings management we thus control for firm-specific variables. These are: firm size (SIZE) measured by the natural logarithm of total assets; firm age (FAGE) measured by the number of years since a firm has been listed on the London Stock Exchange; Business complexity (BSEG) calculated as the logarithm of the number of operating segments of the firm; leverage $(L E V)$ measured by the ratio of total liabilities scaled by total assets; ownership concentration $(O W N)$ measured by the sum of shares held by block-holders of greater than $5 \%$ divided by the total number of shares in issue; and firm profitability (ROA) measured by net income before extraordinary items divided by total assets; a proxy for liquidity (CFO) which represents cash flow from operating activities divided by total assets; the annual growth of sales (Sales_growth) calculated as the change in sales from previous year scaled by sales at the beginning of the year; and industry and year dummies.

\subsection{Empirical Model}

We use the following model to estimate the impact of AC report tone (ACTone) on earnings management (EM). Since earnings management must occur prior to the financial year-end, and AC report is written after the financial year-end (Zang, 2012), we expect that the tone of $\mathrm{AC}$ reports to be associated with earnings management in the following financial year. Therefore, we apply one-year lag between our dependent and independent variables. The measurements are described separately in sections 3.2 
and 3.3, and the control variables are described in section 3.4. All variables are defined in Table 2.

$$
\begin{aligned}
& E M=\beta_{0}+\beta_{1} \text { ACTone }+\beta_{2} \text { ACStrength }+\beta_{3} \text { BODStrength }+\beta_{4} \text { SIZE }+ \\
& \beta_{5} F A G E+\beta_{6} B S E G+\beta_{7} L E V+\beta_{8} \text { OWN }+\beta_{9} R O A+\beta_{10} C F O+ \\
& \beta_{11} \text { Sales_growth }+\beta_{12} \text { Industrydummies }+\beta_{13} \text { Yeardummies }+\epsilon
\end{aligned}
$$

[Table 2 about here]

\section{EMPIRICAL RESULTS}

\subsection{Descriptive Statistics and Correlations}

Table 3 presents the descriptive statistics for the variables in our model. The mean values of real earnings management variable (EM_RM) is -0.0328 which is higher than the mean value of -0.006 reported in Cheng et al. (2015), and the mean value of performance-matched real earnings management (EM_PRM) is -0.0185 . The mean value of accrual-based earnings management (EM_MJM) is -0.0292 , and the mean value of performance-matched accrual-based earnings is -0.0095 . The mean value of our financial reporting quality index (FRQ_index) is -0.0138 . The AC disclosure tone measures viz. ACT_Litigious and ACT_Constrain show that 0.375 of the words in the AC reports are included in Loughran and McDonald Litigious Word List and 0.508 of the words are included in Loughran and McDonald Constrain Word List respectively. The mean value of the aggregate tone measure $\left(A C T \_L I W C\right)$ is 1.401 which is higher than the mean value of 0.901 reported in Smith (2019) based on the positive and negative words in the LIWC word lists. 
Table 4 reports the Pearson correlation for the variables in our main analysis we find that $A C T \_$Litigious, $A C T$ Constrain are negatively associated with real earnings management (EM_RM) and correlation coefficients are significant at the 5\% level. $A C T \_L I W C$ is also negatively associated with $E M \_R M$, the correlation coefficient is significant at $10 \%$ level. These coefficients suggest a negative correlation between AC disclosure tone and earnings management. ACStrength and BODStrength are also negatively correlated with earnings management. None of the correlations between control variables are high enough to raise a multicollinearity issue as the variance inflation factor (VIF) values range from 1.07 and 2.75 With a mean value of 2.17.

[Table 3 and 4 about here]

\subsection{AC Report Disclosure Tone and Real Earnings Management}

Table 5 presents our main findings on the impact of AC disclosure tone and financial reporting quality measured by real earnings management (EM_RM) and performance-matched real earnings management (EM_PRM). Models 5.1 and 5.2 use ACT_Litigious, Models 5.3 and 5.4 use ACT_Constrain, and Models 5.5 and 5.6 use $A C T \_L I W C$ as the AC disclosure tone measure. Our results show that ACT_Litigious has a negative and significant association with $E M \_R M$ at 5\% level and at 5\% level with EM_PRM. ACT_Constrain has a negative and significant association with $E M \_R M$ at $1 \%$ level and with $E M \_P R M$ at $5 \%$ level, and $A C T \_L I W C$ has a negative and significant association with $E M \_R M$ at 5\% level and with $E M \_P R M$ at $10 \%$ level.10 The results are also economically significant, where economic significance is

10 We also investigate the impact of AC report positive tone and negative tone on earnings management. our untabulated results reveal that Ac report negative tone is significant and negatively associated with earnings management while AC report positive tone is negatively associated with EM but not significant. 
computed following Huang et al. (2018). For example, Model 5.1 shows that the coefficient of -0.0381 for ACT_Litigious indicates that moving from the first quartile (0.220) to the third quartile (0.500) of ACT_Litigious can decrease a firm's real earnings management by $1.067 \%$. Similarly, in Model 5.3 the coefficient of -0.031 for ACT_Constrain indicates that moving from the first quartile $(0.350)$ to the third quartile (0.650) of ACT_Constrain can decrease a firm's real earnings management by $0.933 \%$. In Model 5.5, the coefficient of -0.0114 for ACT_LIWC indicates that moving from the first quartile (1.224) to the third quartile (1.542) of ACT_LIWC can decrease real earnings management by $0.362 \%$. Therefore, consistent with our hypothesis, we find that the tone of $\mathrm{AC}$ disclosures is associated with lower level of real earnings management activities.

Our results also show that ACStrength has a negative and significant association with real earnings management metrics at $1 \%$ level for Models 5.1-5.6. These findings are consistent with the view that ACs mitigate earnings management by supervising major accounting choices and supporting correction of discovered errors and generally improving quality of reporting and auditing (Klein, 2002; Xie et al., 2003; Piot and Janin, 2007; Zaman et al., 2011; Libby et al., 2015). Among other control variables, we find $L E V$ has a significant and positive association, and Sales_growth has a significant and negative association with real earnings management proxies indicating that both capital structure and growth opportunities are likely to affect real earnings management (Cheng et al., 2016; Katmon and Al Farooque, 2017).

Prior literature argues that REM is less subject to auditor scrutiny (e.g., Kim and Park, 2014). The real economic actions that a company engage in to meet specific earnings targets is difficult to confront by auditors or regulators (Graham et al., 2005). 
We investigate whether $\mathrm{ACs}$ are responding to aggressive REM by disclosing activities that capture the underlying risks of their firms, where ACs and auditors may perceive lower-magnitude $R E M$ as ordinary business operations. We divide the sample into firms that are the top quintile REM (i.e., higher-magnitude $R E M$ ) and firms at the lower quintile REM (i.e., lower-magnitude REM) (see Greiner et al. 2017 for a similar approach). Our untabulated results show that for subsample with highermagnitude REM, ACT_Constrain has a negative and significant association with EM_RM at $10 \%$ level, and with EM_PRM at $1 \%$ level, and $A C T \_L I W C$ has a negative and significant association with EM_RM at 5\% level, and with EM_PRM at 1\% level. For subsample with lower-magnitude $R E M$, AC disclosure tone measures do not show an association with REM proxies suggesting that ACs may perceive lowermagnitude $R E M$ as ordinary business operations and their reporting is more likely to have an effect in constraining higher-magnitude REM rather than lower-magnitude REM. Interestingly, ACStrength has a negative and significant association with real earnings management metrics for lower-magnitude REM subsample, but not for higher levels $R E M$, suggesting that aggressive REM requires additional substantive oversight and AC engagement through AC disclosure activities that capture the increased business risks, more than specific features of ACs.

Our paper contributes to the textual analysis literature. Prior studies explore how the readability of annual reports, used as an aspect of textual analysis, varies with earnings management (Ajina et al., 2016; Lo et al., 2017) and shows that firms most likely to engage in earnings manipulation have difficult to read annual reports. Whereas we focus on the tone of a document, in particular of AC reports, and its association with earnings management. Overall, the evidence in Table 5 suggests that 
the tone of AC disclosures, as expressed in the choice of words used in describing AC engagement, conveys information that affects the communication function of $\mathrm{AC}$ reporting thereby improving reporting quality. ACs disclose activities that capture the underlying risks of their firms by utilizing litigious and constrain words in the AC reports. Such disclosure increases the transparency of AC monitoring and enhances the quality of reporting. Our analysis of AC report tone suggests that AC disclosures are not boilerplate but varied in language choice, and that this is associated with reduced earnings management and hence higher financial reporting quality.

[Table 5 about here]

\subsection{Additional Analyses}

\subsubsection{Alternative measures of earnings management}

We conduct additional analysis using alternative proxies for earnings management. In untabulated test, we use accrual-based earnings management and financial reporting quality index (FRQ_Index) computed as the standardized average of the four proxies of earnings management multiplied by minus one so that it is increasing in reporting quality. In the additional tests we use ACT_Litigious, ACT_Constrain, and ACT_LIWC as the AC tone measure. Our results show that ACT_Litigious has a negative and significant association with EM_MJM at $1 \%$ level and ACT_Constrain has a negative and significant association with EM_MJM at $10 \%$ level. ACT_LIWC does not seem to have a significant association with accrual-based earnings management. ACStrength has a negative and significant association with accrual-based earnings management metrics at $1 \%$ level. 
We further find (results untabulated) that FRQ_Index has a positive and significant association with ACT_Litigious (at 10\% level), ACT_Constrain (at 1\% level) and ACT_LIWC (at 5\% level) indicating that the disclosure tone used in AC reports helps in improving financial reporting quality. Also, ACStrength has a positive and significant association with FRQ_Index at $1 \%$ level. Our findings from these additional tests are consistent with our previous findings and support our hypothesis on the negative association between AC report disclosure tone and earnings management.

Overall, our findings show that tone of audit committee disclosures, reflecting the linguistic choice of audit committees in describing their activity, seems to be communicated in a manner that helps to improve financial reporting quality.

\subsubsection{Controlling for endogeneity}

Although our results indicate that AC disclosure tone is negatively associated with earnings management proxies and helps in improving financial reporting quality, and despite our attempt to include a comprehensive set of control variables, it is possible that there are other underlying factors that drive our results. Firms with high earnings management may have propensity to disclose less or strategically manipulate the tone of disclosures to hide bad news and make earnings management activities less visible. This suggests that earnings management metrics and $\mathrm{AC}$ disclosure tone can be endogenously determined and thus could bias the regression results. Moreover, studies examining voluntary disclosures face selection bias issues (Katmon and $\mathrm{Al}$ Farooque, 2017; Bratten et al., 2019). To address these issues, we conduct two supplementary tests that attempt to control for endogeneity resulting from sample selection bias and omitted variables issue. 
To solve sample selection bias, we employ the Heckman (1979) two-step approach consistent with Katmon and Al Farooque (2017). In the first stage, we run a probit model where the dependent variable is an indicator variable (Constrain_indicator/Litigious_indicator), which equals one for observations where $A C T_{-}$Constrain/ACT_Litigious is greater than the median value and zero for observations where it is less than the median value, and regress it on AC, board and firm-specific variables. We then compute the Inverse Mills Ratio (IMR) and include it in the second-stage regressions reported in Table 6 in order to control for the sample selection bias in our dataset. ${ }^{11}$ Our inferences remain unchanged when using the Heckman (1979) two-step approach.

\section{[Table 6 about here]}

To address the endogeneity that may result from model misspecification, we test the main findings on a matched sample using the propensity score matching technique (PSM). We first run a probit model that uses Constrain_indicator/ Litigious_indicator as the dependent variable and variables that determine AC disclosures such as firm-specific variables, $\mathrm{AC}$ and board variables as regressors. We then estimate the propensity score and match based on it for each year-industry group using a 1\% radius matching approach (Shipman et al., 2017). The quality of the matching performed shows a Rubin's B value below 25\% and a Rubin's $\mathrm{R}$ value between 0.5 and 2, with mostly insignificant differences in the variables between the

\footnotetext{
11 The first step regression is performed in order to obtain the 'Inverse Mill Ratio (IMR)' that can be used in controlling the sample selection bias in our dataset (untabulated).
} 
treatment and control groups. The untabulated results confirm the main findings and the absence of endogeneity bias.

\section{SUMMARY AND CONCLUSIONS}

This paper examines the effect of $\mathrm{AC}$ reporting on financial reporting quality as proxied by earnings management. We focus on AC disclosure tone and use textual analysis to assess the tone of AC reports. We utilise the litigation and constrain word dictionaries created by Loughran and McDonald (2011), measured by the word count frequency in the $\mathrm{AC}$ reports. We also measure the tone of $\mathrm{AC}$ disclosures in terms of an aggregate number measured as the sum of the frequency of positive words and frequency of negative words divided by the total word count using LIWC custom dictionary of positive and negative word lists. We use various measures for earnings management, our proxy for financial reporting quality. Using a sample of FTSE 350 firms, we find AC disclosure tone has a significant and negative association with REM proxies. When we divide the sample into firms at the top quintile $R E M$ and firms at lower levels quintile REM, finding shows that $\mathrm{AC}$ disclosure tone is negatively associated with higher-magnitude REM indicating that $\mathrm{AC}$ reporting helps reduce aggressing earnings behaviour while lower-magnitude REM may be perceived as ordinary business operations.

Our additional tests show that AC disclosure tone has a significant and negative association with accrual-based earnings and a positive and significant association with financial reporting quality index. The results support our hypothesis that the tone of AC disclosures is associated with financial reporting quality as proxied by earnings management. The tone of AC disclosures, as expressed in the choice of 
words used in describing AC activity, seems to convey information that affects the communication function of $\mathrm{AC}$ reporting and thereby help improve reporting quality.

Our paper has a few limitations. Future research could improve on our measurements and examine alternative conceptualisation and measurement of AC engagement and reporting. Future research could also explore to what extent the tone of $\mathrm{AC}$ reports is separate from the tone of other elements of the report. While our paper is an early attempt at extending AC research by focusing on textual analysis of $\mathrm{AC}$ reports and moving beyond $\mathrm{AC}$ characteristics and in complementing qualitative studies, our paper is subject to both data and measurement limitations. Our focus in this paper has been on financial reporting quality as proxied by earnings management. Examining alternative measures of reporting quality as well the impact of $\mathrm{AC}$ reporting on audit quality would make valuable extensions to our paper. Moreover, exploring $\mathrm{AC}$ reporting in different institutional settings and in particular time periods are also potential avenues for extending AC research.

Our paper provides a valuable baseline evidence for future academic research and policy making. It shows that AC disclosures are not boilerplate but are varied in use of language choice and this affects financial reporting quality. Overall, our research suggests that $\mathrm{AC}$ reporting can aid transparency and improve the quality of financial reporting. 


\section{REFERENCES}

Ajina, A., Laouiti, M., \& Msolli, B. (2016). Guiding through the Fog: Does annual report readability reveal earnings management? Research in International Business and Finance, 38, 509-516.

Al-Shaer, H., \& Zaman, M. (2018). Credibility of sustainability reports: The contribution of audit committees. Business strategy and the environment, 27(7), 973-986.

Badolato, P. G., Donelson, D. C., \& Ege, M. (2014). Audit committee financial expertise and earnings management: The role of status. Journal of Accounting and Economics, 58(2-3), 208-230.

Baginski, S. P., Hassell, J. M., \& Kimbrough, M. D. (2002). The effect of legal environment on voluntary disclosure: Evidence from management earnings forecasts issued in US and Canadian markets. The Accounting Review, 77(1), 2550 .

Bassyouny, H., Abdelfattah, T., \& Tao, L. (2020). Beyond narrative disclosure tone: The upper echelons theory perspective. International Review of Financial Analysis, 101499.

Beasley, M. S., Carcello, J. V., Hermanson, D. R., \& Neal, T. L. (2009). The audit committee oversight process. Contemporary Accounting Research, 26(1), 65-122.

Bédard, J., \& Gendron, Y. (2010). Strengthening the financial reporting system: Can audit committees deliver?. International Journal of Auditing, 14(2), 174-210.

Bedard, J., Chtourou, S. M., \& Courteau, L. (2004). The effect of audit committee expertise, independence, and activity on aggressive earnings management. Auditing: A Journal of Practice and Theory, 23(2), 13-35.

Bicudo de Castro, V., Gul, F. A., Muttakin, M. B., \& Mihret, D. G. (2019). Optimistic tone and audit fees: Some Australian evidence. International Journal of Auditing, 23(2), 352-364.

Biddle, G. C., Hilary, G., \& Verdi, R. S. (2009). How does financial reporting quality relate to investment efficiency? Journal of Accounting and Economics, 48(2-3), 112131.

Black, B., Cheffins, B., \& Klausner, M. (2005). Liability risk for outside directors: A cross-border analysis. European Financial Management, 11(2), 153-171.

Bodnaruk, A., Loughran, T., \& McDonald, B. (2015). Using 10-K text to gauge financial constraints. Journal of Financial and Quantitative Analysis, 50(4), 623-646.

Bratten, B., Causholli, M., \& Sulcaj, V. (2020). Overseeing the external audit function: Evidence from audit committees' reported activities. Available at SSRN 3314334.

Broye, G., \& Johannes, P. (2021). Determinants of audit committee effectiveness: Reviewing a decade of empirical research. Accounting Auditing Control, 27(1), 51-109.

Carcello, J. V., Hermanson, D. R., \& Neal, T. L. (2002). Disclosures in audit committee charters and reports. Accounting Horizons, 16(4), 291-304.

Cheng, Q., Lee, J., \& Shevlin, T. (2016). Internal governance and real earnings management. The Accounting Review, 91(4), 1051-1085.

Clatworthy, M., \& Jones, M. J. (2003). Financial reporting of good news and bad news: evidence from accounting narratives. Accounting and Business Research, 33(3), $171-185$. 
Cohen, D. A., \& Zarowin, P. (2010). Accrual-based and real earnings management activities around seasoned equity offerings. Journal of Accounting and Economics, 50(1), 2-19.

Cohen, J. R., Hoitash, U., Krishnamoorthy, G., \& Wright, A. M. (2013). The effect of audit committee industry expertise on monitoring the financial reporting process. The Accounting Review, 89(1), 243-273.

Collier, P. \& Zaman, M. (2005). Convergence in European corporate governance: the audit committee concept. Corporate Governance: An International Review, 13(6), 753-768.

Collins, D. W., Pungaliya, R. S., \& Vijh, A. M. (2016). The effects of firm growth and model specification choices on tests of earnings management in quarterly settings. The Accounting Review, 92(2), 69-100.

Compernolle, T. (2018). Communication of the external auditor with the audit committee: Managing impressions to deal with multiple accountability relationships. Accounting, Auditing \& Accountability Journal, 31(3), 900-924.

Coram, P. J., Mock, T. J., Turner, J. L., \& Gray, G. L. (2011). The communicative value of the auditor's report. Australian Accounting Review, 21(3), 235-252.

Czerney, K., Schmidt, J. J., \& Thompson, A. M. (2019). Do investors respond to explanatory language included in unqualified audit reports?. Contemporary Accounting Research, 36(1), 198-229.

Davis, A. K., \& Tama-Sweet, I. (2012). Managers' use of language across alternative disclosure outlets: earnings press releases versus MD\&A. Contemporary Accounting Research, 29(3), 804-837.

Davis, A. K., Piger, J. M., \& Sedor, L. M. (2012). Beyond the numbers: Measuring the information content of earnings press release language. Contemporary Accounting Research, 29(3), 845-868.

Dechow, P. M., Sloan, R. G., \& Sweeney, A. P. (1995). Detecting earnings management. Accounting Review, 193-225.

DeFond, M. L., \& Jiambalvo, J. (1994). Debt covenant violation and manipulation of accruals. Journal of Accounting and Economics, 17(1-2), 145-176.

Dhaliwal, D. A. N., Naiker, V. I. C., \& Navissi, F. (2010). The association between accruals quality and the characteristics of accounting experts and mix of expertise on audit committees. Contemporary Accounting Research, 27(3), 787827.

Doukakis, L. C. (2014). The effect of mandatory IFRS adoption on real and accrualbased earnings management activities. Journal of Accounting and Public Policy, 33(6), 551-572.

Draeger, M., Lawson, B., \& Schmidt, J. J. (2019). Does audit committee reporting need to be improved? Evidence from a large-scale textual analysis. Working Paper.

Ertugrul, M., Lei, J., Qiu, J., \& Wan, C. (2017). Annual report readability, tone ambiguity, and the cost of borrowing. Journal of Financial and Quantitative Analysis, 52(2), 811-836.

Francis, J., Philbrick, D., \& Schipper, K. (1994). Shareholder litigation and corporate disclosures. Journal of Accounting Research, 32, 137-164.

FRC. (2010). Guidance on Audit Committees. London: Financial Reporting Council.

FRC. (2012a). Guidance on Audit Committees. London: Financial Reporting Council. 
FRC. (2012b). What Constitutes an Explanation under 'Comply or Explain'? Report of Discussions between Companies and Investors. London: Financial Reporting Council.

Gendron, Y., \& Bédard, J. (2006). On the constitution of audit committee effectiveness. Accounting, Organizations and Society, 31(3), 211-239.

Ghafran, C., \& O'Sullivan, N. (2013). The governance role of audit committees: reviewing a decade of evidence. International Journal of Management Reviews, 15(4), 381-407.

Ghafran, C., \& O'Sullivan, N. (2017). The impact of audit committee expertise on audit quality: Evidence from UK audit fees. The British Accounting Review, 49(6), 578593.

Ghosh, A., Marra, A., \& Moon, D. (2010). Corporate boards, audit committees, and earnings management: pre-and post-SOX evidence. Journal of Business Finance $\mathcal{E}$ Accounting, 37(9-10), 1145-1176.

Graham, J. R., Harvey, C. R., \& Rajgopal, S. (2005). The economic implications of corporate financial reporting. Journal of Accounting and Economics, 40(1-3), 3-73.

Greiner, A., Kohlbeck, M. J., \& Smith, T. J. (2017). The relationship between aggressive real earnings management and current and future audit fees. Auditing: A Journal of Practice $\mathcal{E}$ Theory, 36(1), 85-107.

Gutierrez, E., Minutti-Meza, M., Tatum, K. W., \& Vulcheva, M. (2018). Consequences of adopting an expanded auditor's report in the United Kingdom. Review of Accounting Studies, 23(4), 1543-1587.

Healy, P. M. \& Palepu, K. G. (2001). Information asymmetry, corporate disclosure, and the capital markets: A review of the empirical disclosure literature. Journal of Accounting and Economics, 31(1-3), 405-440.

Heckman, J. (1979). Sample selection bias as a specification error. Econometrica, 47(1), 153-161.

Huang, X., Teoh, S. H., \& Zhang, Y. (2013). Tone management. The Accounting Review, 89(3), 1083-1113.

Jo, H., \& Kim, Y. (2007). Disclosure frequency and earnings management. Journal of Financial Economics, 84(2), 561-590.

Jones, J. J. (1991). Earnings management during import relief investigations. Journal of Accounting Research, 193-228.

Kang, T., Park, D. H., \& Han, I. (2018). Beyond the numbers: The effect of 10-K tone on firms' performance predictions using text analytics. Telematics and Informatics, 35(2), 370-381.

Kim, J., Kim, Y., \& Zhou, J. (2017). Languages and earnings management. Journal of Accounting and Economics, 63(2-3), 288-306.

Kim, Y., \& Park, M. S. (2014). Real activities manipulation and auditors' clientretention decisions. The Accounting Review, 89(1), 367-401.

Katmon, N., \& Al Farooque, O. (2017). Exploring the impact of internal corporate governance on the relation between disclosure quality and earnings management in the UK listed companies. Journal of Business Ethics, 142(2), 345367.

Khemakhem, H., \& Fontaine, R. (2019). The audit committee chair's abilities: Beyond financial expertise. International Journal of Auditing, 23(3), 457-471.

Klein, A. (2002). Audit committee, board of director characteristics, and earnings management. Journal of Accounting and Economics, 33(3), 375-400. 
Kothari, S. P., Leone, A. J., \& Wasley, C. E. (2005). Performance matched discretionary accrual measures. Journal of Accounting and Economics, 39(1), 163-197.

Kothari, S. P., Li, X., \& Short, J. E. (2009). The effect of disclosures by management, analysts, and business press on cost of capital, return volatility, and analyst forecasts: A study using content analysis. The Accounting Review, 84(5), 16391670.

Larcker, D. F., \& Zakolyukina, A. A. (2012). Detecting deceptive discussions in conference calls. Journal of Accounting Research, 50(2), 495-540.

Lehavy, R., Li, F., \& Merkley, K. (2011). The effect of annual report readability on analyst following and the properties of their earnings forecasts. The Accounting Review, 86(3), 1087-1115.

Lennox, C. S., Schmidt, J. J., \& Thompson, A. (2018). Is the expanded model of audit reporting informative to investors? Evidence from the UK. Working paper.

Li, F. (2008). Annual report readability, current earnings, and earnings persistence. Journal of Accounting and Economics, 45(2-3), 221-247.

Li, J., Mangena, M., \& Pike, R. (2012). The effect of audit committee characteristics on intellectual capital disclosure. The British Accounting Review, 44(2), 98-110.

Libby, R., Rennekamp, K. M., \& Seybert, N. (2015). Regulation and the interdependent roles of managers, auditors, and directors in earnings management and accounting choice. Accounting, Organizations and Society, 47, 25-42.

Lo, K., Ramos, F., \& Rogo, R. (2017). Earnings management and annual report readability. Journal of Accounting and Economics, 63(1), 1-25.

Loughran, T., \& McDonald, B. (2011). When is a liability not a liability? Textual analysis, dictionaries, and 10-Ks. The Journal of Finance, 66(1), 35-65.

Loughran, T., \& McDonald, B. (2014). Measuring readability in financial disclosures. The Journal of Finance, 69(4), 1643-1671.

Luo, J. H., Li, X., \& Chen, H. (2018). Annual report readability and corporate agency costs. China Journal of Accounting Research, 11(3), 187-212.

Mangena, M. \& Pike, R. (2005). The effect of audit committee shareholding, financial expertise and size on interim financial disclosures. Accounting and Business Research, 35, 327-349.

Mangena, M., \& Tauringana, V. (2008). Audit committees and voluntary external auditor involvement in UK interim reporting. International Journal of Auditing, 12(1), 45-63.

McNulty, T., Zattoni, A., \& Douglas, T. (2013). Developing corporate governance research through qualitative methods: A review of previous studies. Corporate Governance: An International Review, 21(2), 183-198.

Miller, B. P. (2010). The effects of reporting complexity on small and large investor trading. The Accounting Review, 85(6), 2107-2143.

Mouselli, S., Jaafar, A., \& Hussainey, K. (2012). Accruals quality vis-à-vis disclosure quality: Substitutes or complements?. The British Accounting Review, 44(1), 3646.

Owens, E. L., Wu, J. S., \& Zimmerman, J. (2017). Idiosyncratic shocks to firm underlying economics and abnormal accruals. The Accounting Review, 92(2), 183-219.

Peasnell, K. V., Pope, P. F., \& Young, S. (2005). Board monitoring and earnings management: Do outside directors influence abnormal accruals? Journal of Business Finance and Accounting, 32(7-8), 1311-1346. 
Piot, C., \& Janin, R. (2007). External auditors, audit committees and earnings management in France. European Accounting Review, 16(2), 429-454.

Purda, L., \& Skillicorn, D. (2015). Accounting variables, deception, and a bag of words: Assessing the tools of fraud detection. Contemporary Accounting Research, 32(3), 1193-1223.

Reid, L.C., Carcello, J.V., Li, C. \& Neal, T.L. (2019). Impact of auditor report changes on financial reporting quality and audit costs: evidence from the United Kingdom. Contemporary Accounting Research, 36(3), 1501-1539.

Roychowdhury, S. (2006). Earnings management through real activities manipulation. Journal of Accounting and Economics, 42(3), 335-370.

Sahyoun, N., \& Magnan, M. (2020). The association between voluntary disclosure in audit committee reports and banks' earnings management. Managerial Auditing Journal

Samaha, K., Khlif, H., \& Hussainey, K. (2015). The impact of board and audit committee characteristics on voluntary disclosure: A meta-analysis. Journal of International Accounting, Auditing and Taxation, 24, 13-28.

Shipman, J. E., Swanquist, Q. T., \& Whited, R. L. (2017). Propensity score matching in accounting research. The Accounting Review, 92(1), 213-244.

Smith, K. (2019). Tell me more: a content analysis of expanded auditor reporting in the United Kingdom. Working Paper.

Tetlock, P. C. (2007). Giving content to investor sentiment: The role of media in the stock market. The Journal of Finance, 62(3), 1139-1168.

Tetlock, P. C., Saar-Tsechansky, M., \& Macskassy, S. (2008). More than words: Quantifying language to measure firms' fundamentals. The Journal of Finance, 63(3), 1437-1467.

Trotman, A. J., \& Trotman, K. T. (2013). Internal audit's role in GHG emissions and energy reporting: Evidence from audit committees, senior accountants, and internal auditors. Auditing: A Journal of Practice $\mathcal{E}$ Theory, 34(1), 199-230.

Turley, S., \& Zaman, M. (2007). Audit committee effectiveness: informal processes and behavioural effects. Accounting, Auditing $\mathcal{E}$ Accountability Journal, 20(5), 765788.

Xie, B., Davidson, W. N., \& DaDalt, P. J. (2003). Earnings management and corporate governance: the role of the board and the audit committee. Journal of Corporate Finance, 9(3), 295-316.

Yekini, L. S., Wisniewski, T. P., \& Millo, Y. (2016). Market reaction to the positiveness of annual report narratives. The British Accounting Review, 48(4), 415-430.

You, H., \& Zhang, X. J. (2009). Financial reporting complexity and investor underreaction to 10-K information. Review of Accounting studies, 14(4), 559-586.

Zaman, M., Hudaib, M., \& Haniffa, R. (2011). Corporate governance quality, audit fees and non-audit services fees. Journal of Business Finance $\mathcal{E}$ Accounting, 38(1-2), 165-197.

Zang, A. Y. (2012). Evidence on the trade-off between real activities manipulation and accrual-based earnings management. The Accounting Review, 87(2), 675-703.

Zhou, H., Owusu-Ansah, S., \& Maggina, A. (2018). Board of directors, audit committee, and firm performance: Evidence from Greece.Journal of International Accounting, Auditing and Taxation, 31, 20-36. 
Table 1: Sample

FTSE350 companies

Less:

Banks and Insurance

Utilities

Missing data

Final sample
700 firm-years

(130) firm-years

(14) firm-years

(16) firm-years

540 firm-years 


\section{Table 2: Variable Definitions}

\begin{tabular}{|c|c|}
\hline Variable & Definitions \\
\hline EM_MJM & Discretionary accruals estimated using the modified Jones (1991) model. \\
\hline EM_PEM & $\begin{array}{l}\text { Performance-matched earnings management proxy following Kothari et al. } \\
\text { (2005) }\end{array}$ \\
\hline EM_RM & $\begin{array}{l}\text { An aggregate measure of real earnings management activities and is calculated } \\
\text { as the sum of abnormal discretionary expenses multiplied by negative one and } \\
\text { abnormal production costs. }\end{array}$ \\
\hline EM_PRM & $\begin{array}{l}\text { Performance-matched real earnings management proxy following Kothari et al. } \\
\text { (2005) }\end{array}$ \\
\hline FRQ_index & $\begin{array}{l}\text { The financial reporting quality index is computed as the standardized average of } \\
\text { the four proxies of earnings management multiplied by minus one so that it is } \\
\text { increasing in reporting quality following Biddle et al. (2009). }\end{array}$ \\
\hline ACT_Litigious & $\begin{array}{l}\text { Represents the word count frequency in the audit report based on the Loughran } \\
\text { and McDonald Litigious Word List. }\end{array}$ \\
\hline ACT_Constrain & $\begin{array}{l}\text { Represents the word count frequency in the audit report based on the Loughran } \\
\text { and McDonald Constrain Word List }\end{array}$ \\
\hline ACT_LIWC & $\begin{array}{l}\text { Calculated as (POSITIVE-NEGATIVE)/total word count, where POSITIVE and } \\
\text { NEGATIVE refer to the word count frequency based on the positive and } \\
\text { negative words in the LIWC word lists, respectively. }\end{array}$ \\
\hline ACStrength & $\begin{array}{l}\text { Index measures the strength of audit committee computed by totalling the } \\
\text { proxies of five AC characteristics: ACSIZE: Dummy variable if number of AC } \\
\text { members is higher than the industry median } 1 \text {, otherwise 0; ACIND: Dummy } \\
\text { variable if the percentage of independent directors on audit committee is higher } \\
\text { than the industry median 1, otherwise 0; ACMEET: Dummy variable if number } \\
\text { of AC meetings is higher than the industry median 1, otherwise 0; ACEXP: } \\
\text { Dummy variable if the number of AC members with financial expertise is higher } \\
\text { than the industry median 1, otherwise 0; ACF: Dummy variable if the number of } \\
\text { female members on audit committee is higher than the industry median 1, } \\
\text { otherwise } 0\end{array}$ \\
\hline BODStrength & $\begin{array}{l}\text { Index measures the strength of corporate board computed by totalling the } \\
\text { proxies of six board characteristics: BODSIZE: Dummy variable if number of } \\
\text { board members is higher than the industry median 1, otherwise 0; BODIND: } \\
\text { Dummy variable if the percentage of independent directors on board is higher } \\
\text { than the industry median } 1 \text {, otherwise 0; BODMEET: Dummy variable if number } \\
\text { of board meetings is higher than the industry median 1, otherwise 0; BODEXP: } \\
\text { Dummy variable if the percentage of board members with financial expertise is } \\
\text { higher than the industry median } 1 \text {, otherwise 0; BODF: Dummy variable if the } \\
\text { percentage of female directors on board is higher than the industry median } 1 \text {, } \\
\text { otherwise } 0 \text {; DUALITY: Dummy variable if the chief executive officer (CEO) and } \\
\text { board chair role is separate } 1 \text {, otherwise } 0 \text {. }\end{array}$ \\
\hline SIZE & Firm size: Natural logarithm of firm's total assets. \\
\hline FAGE & Number of years since a firm listed on the London Stock Exchange. \\
\hline BSEG & $\begin{array}{l}\text { Represents the complexity of the business calculated as the logarithm of the } \\
\text { number of operating segments of the firm }\end{array}$ \\
\hline LEV & Systematic risks: Ratio of total liabilities divided by total assets. \\
\hline OWN & $\begin{array}{l}\text { The sum of shares held by block-holders of greater than } 5 \% \text { divided by the total } \\
\text { number of shares in issue. }\end{array}$ \\
\hline ROA & $\begin{array}{l}\text { Firm profitability: measured using Net income before extraordinary item } \\
\text { divided by total assets. }\end{array}$ \\
\hline $\mathrm{CFO}$ & $\begin{array}{l}\text { A proxy for liquidity which represents cash flow from operating activities } \\
\text { divided by total assets }\end{array}$ \\
\hline Sales_growth & $\begin{array}{l}\text { The annual growth of sales calculated as the change in sales from previous year } \\
\text { scaled by sales at the beginning of the year }\end{array}$ \\
\hline
\end{tabular}


Table 3: Descriptive Statistics

\begin{tabular}{lccccc}
\hline Variable & N & Mean & SD & Min & Max \\
\hline EM_RM & 540 & -0.033 & 0.359 & -0.978 & 0.752 \\
EM_PRM & 540 & -0.019 & 0.349 & -0.983 & 0.715 \\
EM_MJM & 540 & -0.029 & 0.056 & -0.441 & 0.165 \\
EM_PEM & 540 & -0.010 & 0.054 & -0.251 & 0.217 \\
FRQ_index & 540 & -0.014 & 0.108 & -0.518 & 0.362 \\
ACT_Litigious & 540 & 0.375 & 0.221 & 0.000 & 5.818 \\
ACT_Constrain & 540 & 0.508 & 0.222 & 0.000 & 5.792 \\
ACT_LIWC & 540 & 1.401 & 0.307 & -0.880 & 2.662 \\
ACStrength & 540 & 2.397 & 1.160 & 0.000 & 5.000 \\
BODStrength & 540 & 1.956 & 1.433 & 0.000 & 5.000 \\
SIZE & 540 & 14.552 & 1.434 & 10.402 & 19.942 \\
FAGE & 540 & 23.557 & 20.462 & 0.000 & 69.000 \\
BSEG & 540 & 3.312 & 2.424 & 1.000 & 10.000 \\
LEV & 540 & 0.534 & 0.297 & 0.003 & 1.547 \\
OWN & 540 & 4.416 & 0.285 & 3.258 & 4.605 \\
ROA & 540 & 0.083 & 0.077 & -0.147 & 0.325 \\
CFO & 540 & 0.109 & 0.172 & -0.081 & 2.819 \\
Sales_growth & 540 & 0.023 & 0.384 & -2.231 & 1.044 \\
\hline Var & & & & \\
\hline
\end{tabular}

Variables winsorised to adjust for outliers. Variables are as defined in Table 2. 
Table 4: Correlation Matrix

\begin{tabular}{|c|c|c|c|c|c|c|c|c|c|c|c|c|c|c|c|}
\hline & Variable & 1 & 2 & 3 & 4 & 5 & 6 & 7 & 8 & 9 & 10 & 11 & 12 & 13 & 14 \\
\hline 1 & EM_RM & 1 & & & & & & & & & & & & & \\
\hline 2 & ACT_Litigious & $-0.1146^{* *}$ & 1 & & & & & & & & & & & & \\
\hline 3 & ACT_Constrain & $-0.1565^{\star *}$ & $0.5689^{*}$ & 1 & & & & & & & & & & & \\
\hline 4 & ACT_LIWC & $-0.078^{*}$ & $0.2930^{*}$ & $0.3165^{*}$ & 1 & & & & & & & & & & \\
\hline 5 & ACStrength & $-0.1326^{* *}$ & $0.1429^{*}$ & $0.1678^{*}$ & $0.1028^{*}$ & 1 & & & & & & & & & \\
\hline 6 & BODStrength & -0.0749 & $0.2127^{*}$ & $0.1663^{*}$ & 0.0587 & $0.4247^{*}$ & 1 & & & & & & & & \\
\hline 7 & SIZE & -0.0247 & $0.3195^{*}$ & $0.2989^{*}$ & $0.1472^{*}$ & $0.2765^{*}$ & $0.5072^{*}$ & 1 & & & & & & & \\
\hline 8 & FAGE & 0.0688 & -0.0691 & -0.0558 & -0.0357 & -0.0148 & 0.03 & $0.0892^{*}$ & 1 & & & & & & \\
\hline 9 & BSEG & -0.0572 & $0.1881^{*}$ & $0.1645^{*}$ & 0.0266 & $0.1524^{*}$ & $0.2712^{*}$ & $0.2041^{*}$ & 0.0042 & 1 & & & & & \\
\hline 10 & LEV & 0.0139 & $0.0837^{* *}$ & $0.0868^{* *}$ & $0.0900^{*}$ & $0.2598^{*}$ & $0.2958^{*}$ & $0.2534^{*}$ & $-0.1518^{*}$ & $0.2145^{*}$ & 1 & & & & \\
\hline 11 & OWN & $0.0949^{*}$ & -0.0401 & -0.0705 & -0.0714 & 0.0682 & -0.0041 & -0.0068 & $0.2437^{*}$ & $-0.0840^{*}$ & 0.0479 & 1 & & & \\
\hline 12 & ROA & 0.0042 & -0.0756 & $-0.1554^{*}$ & -0.0554 & -0.0624 & $-0.0970^{*}$ & $-0.1686^{*}$ & $0.0952^{*}$ & -0.0772 & $-0.1157^{*}$ & 0.0785 & 1 & & \\
\hline 13 & $\mathrm{CFO}$ & -0.0627 & -0.0516 & -0.0128 & 0.0067 & $0.1582^{*}$ & 0.0704 & $-0.2541^{*}$ & $-0.1313^{*}$ & $0.0928^{*}$ & $0.1177^{*}$ & -0.0263 & $0.1182^{*}$ & 1 & \\
\hline 14 & Sales_growth & -0.0224 & 0.0144 & 0.043 & 0.0148 & 0.0492 & 0.0207 & 0.0092 & -0.0072 & 0.0297 & 0.0765 & -0.0218 & 0.0537 & 0.0238 & 1 \\
\hline
\end{tabular}


Table 5: AC Report Disclosure Tone and Real Earnings Management

\begin{tabular}{|c|c|c|c|c|c|c|}
\hline Variables & EM_RM & EM_PRM & EM_RM & EM_PRM & EM_RM & EM_PRM \\
\hline & Model 5.1 & Model 5.2 & Model 5.3 & Model 5.4 & Model 5.5 & Model 5.6 \\
\hline ACT_Litigious & $\begin{array}{c}-0.0381^{* *} \\
{[-2.41]}\end{array}$ & $\begin{array}{c}-0.0351^{* *} \\
{[-2.25]}\end{array}$ & & & & \\
\hline ACT_Constrain & & & $\begin{array}{c}-0.0311^{* * *} \\
{[-2.92]}\end{array}$ & $\begin{array}{c}-0.0260^{* *} \\
{[-2.49]}\end{array}$ & & \\
\hline ACT_LIWC & & & & & $\begin{array}{c}-0.0114^{* *} \\
{[-1.97]}\end{array}$ & $\begin{array}{c}-0.0114^{*} \\
{[-1.94]}\end{array}$ \\
\hline ACStrength & $\begin{array}{c}-0.0493^{* * *} \\
{[-2.98]}\end{array}$ & $\begin{array}{c}-0.0416^{* *} \\
{[-2.55]}\end{array}$ & $\begin{array}{c}-0.0364^{* * *} \\
{[-3.97]}\end{array}$ & $\begin{array}{c}-0.0308^{* * *} \\
{[-3.43]}\end{array}$ & $\begin{array}{c}-0.0376^{* * *} \\
{[-3.99]}\end{array}$ & $\begin{array}{c}-0.0317^{* * *} \\
{[-3.44]}\end{array}$ \\
\hline BODStrength & $\begin{array}{c}-0.0044 \\
{[-0.31]}\end{array}$ & $\begin{array}{c}-0.0035 \\
{[-0.26]}\end{array}$ & $\begin{array}{c}-0.0005 \\
{[-0.06]}\end{array}$ & $\begin{array}{c}-0.0004 \\
{[-0.05]}\end{array}$ & $\begin{array}{r}-0.0008 \\
{[-0.09]}\end{array}$ & $\begin{array}{c}-0.0008 \\
{[-0.10]}\end{array}$ \\
\hline SIZE & $\begin{array}{c}-0.0035 \\
{[-0.24]}\end{array}$ & $\begin{array}{l}0.0226 \\
{[1.62]}\end{array}$ & $\begin{array}{c}-0.0088 \\
{[-1.06]}\end{array}$ & $\begin{array}{l}0.0104 \\
{[1.32]}\end{array}$ & $\begin{array}{c}-0.0118 \\
{[-1.44]}\end{array}$ & $\begin{array}{l}0.0083 \\
{[1.07]}\end{array}$ \\
\hline FAGE & $\begin{array}{l}0.0004 \\
{[0.59]}\end{array}$ & $\begin{array}{l}0.0003 \\
{[0.41]}\end{array}$ & $\begin{array}{l}0.0004 \\
{[1.14]}\end{array}$ & $\begin{array}{l}0.0004 \\
{[1.09]}\end{array}$ & $\begin{array}{l}0.0005 \\
{[1.23]}\end{array}$ & $\begin{array}{l}0.0005 \\
{[1.15]}\end{array}$ \\
\hline BSEG & $\begin{array}{c}-0.0079 \\
{[-1.03]}\end{array}$ & $\begin{array}{c}-0.0112 \\
{[-1.50]}\end{array}$ & $\begin{array}{c}-0.0046 \\
{[-1.06]}\end{array}$ & $\begin{array}{l}-0.0067 \\
{[-1.59]}\end{array}$ & $\begin{array}{l}-0.0056 \\
{[-1.23]}\end{array}$ & $\begin{array}{c}-0.0076^{*} \\
{[-1.72]}\end{array}$ \\
\hline LEV & $\begin{array}{c}0.1970^{* * *} \\
{[3.31]}\end{array}$ & $\begin{array}{c}0.1560 * * * \\
{[2.63]}\end{array}$ & $\begin{array}{c}0.1461^{* * *} \\
{[4.03]}\end{array}$ & $\begin{array}{c}0.1140^{* * *} \\
{[3.18]}\end{array}$ & $\begin{array}{c}0.1521^{* * *} \\
{[4.08]}\end{array}$ & $\begin{array}{c}0.1193^{* * *} \\
{[3.26]}\end{array}$ \\
\hline OWN & $\begin{array}{c}0.1284^{* * *} \\
{[2.81]}\end{array}$ & $\begin{array}{c}0.1323^{* * *} \\
{[2.96]}\end{array}$ & $\begin{array}{c}0.0635^{* *} \\
{[2.10]}\end{array}$ & $\begin{array}{c}0.0690^{* *} \\
{[2.31]}\end{array}$ & $\begin{array}{c}0.0655^{* *} \\
{[2.15]}\end{array}$ & $\begin{array}{c}0.0701^{* *} \\
{[2.33]}\end{array}$ \\
\hline ROA & $\begin{array}{c}0.0256 \\
{[0.11]}\end{array}$ & $\begin{array}{c}0.0911 \\
{[0.41]}\end{array}$ & $\begin{array}{l}0.0072 \\
{[0.05]}\end{array}$ & $\begin{array}{l}0.0416 \\
{[0.30]}\end{array}$ & $\begin{array}{c}0.02 \\
{[0.13]}\end{array}$ & $\begin{array}{l}0.0522 \\
{[0.36]}\end{array}$ \\
\hline $\mathrm{CFO}$ & $\begin{array}{c}-0.0874 \\
{[-0.56]}\end{array}$ & $\begin{array}{l}-0.0176 \\
{[-0.13]}\end{array}$ & $\begin{array}{l}-0.1243 \\
{[-1.10]}\end{array}$ & $\begin{array}{r}-0.0715 \\
{[-0.70]}\end{array}$ & $\begin{array}{c}-0.1205 \\
{[-1.07]}\end{array}$ & $\begin{array}{c}-0.0677 \\
{[-0.67]}\end{array}$ \\
\hline Sales_growth & $\begin{array}{c}-0.0020^{* * *} \\
{[-2.80]}\end{array}$ & $\begin{array}{c}-0.0022^{* * *} \\
{[-3.05]}\end{array}$ & $\begin{array}{c}-0.0006 \\
{[-1.51]}\end{array}$ & $\begin{array}{c}-0.0007^{*} \\
{[-1.84]}\end{array}$ & $\begin{array}{c}-0.0010^{* *} \\
{[-2.20]}\end{array}$ & $\begin{array}{c}-0.0011^{* *} \\
{[-2.45]}\end{array}$ \\
\hline Industry dummy & Included & Included & Included & Included & Included & Included \\
\hline Year dummy & Included & Included & Included & Included & Included & Included \\
\hline Intercept & $\begin{array}{c}-0.5375^{*} \\
{[-1.96]}\end{array}$ & $\begin{array}{c}-0.8127^{* * *} \\
{[-3.11]}\end{array}$ & $\begin{array}{l}-0.135 \\
{[-0.75]}\end{array}$ & $\begin{array}{c}-0.3578^{* *} \\
{[-2.08]}\end{array}$ & $\begin{array}{c}-0.1414 \\
{[-0.78]}\end{array}$ & $\begin{array}{c}-0.3620^{* *} \\
{[-2.09]}\end{array}$ \\
\hline R-squared & 0.0679 & 0.0578 & 0.1065 & 0.0803 & 0.0958 & 0.0737 \\
\hline $\mathrm{N}$ & 540 & 540 & 540 & 540 & 540 & 540 \\
\hline
\end{tabular}



Table 6: AC Report Disclosure Tone and Earnings Management:
Heckman (1979) two-step Approach

\begin{tabular}{|c|c|c|c|c|}
\hline Variables & EM_RM & EM_PRM & EM_RM & EM_PRM \\
\hline & Model 6.1 & Model 6.2 & Model 6.3 & Model 6.4 \\
\hline ACT_Constrain & $\begin{array}{c}-0.0597^{* *} \\
{[-1.99]}\end{array}$ & $\begin{array}{c}-0.0271 \\
{[-1.57]}\end{array}$ & & \\
\hline ACT_Litigious & & & $\begin{array}{c}-0.0459 * * \\
{[-1.97]}\end{array}$ & $\begin{array}{c}-0.0517^{* *} \\
{[-2.30]}\end{array}$ \\
\hline ACStrength & $\begin{array}{c}-0.0509^{* * *} \\
{[-2.76]}\end{array}$ & $\begin{array}{c}-0.0192^{*} \\
{[-1.81]}\end{array}$ & $\begin{array}{c}-0.0534^{* * *} \\
{[-3.04]}\end{array}$ & $\begin{array}{c}-0.0317^{*} \\
{[-1.86]}\end{array}$ \\
\hline BODStrength & $\begin{array}{c}-0.0164 \\
{[-0.33]}\end{array}$ & $\begin{array}{c}-0.0164 \\
{[-0.33]}\end{array}$ & $\begin{array}{c}0.0269 \\
{[0.54]}\end{array}$ & $\begin{array}{c}0.0269 \\
{[0.54]}\end{array}$ \\
\hline SIZE & $\begin{array}{c}0.2178^{* * *} \\
{[3.97]}\end{array}$ & $\begin{array}{c}0.2178^{* * *} \\
{[3.97]}\end{array}$ & $\begin{array}{c}0.2677^{* * *} \\
{[4.75]}\end{array}$ & $\begin{array}{c}0.2677^{* * *} \\
{[4.75]}\end{array}$ \\
\hline FAGE & $\begin{array}{c}-0.0033 \\
{[-1.11]}\end{array}$ & $\begin{array}{c}-0.0033 \\
{[-1.11]}\end{array}$ & $\begin{array}{c}-0.0062^{* *} \\
{[-2.08]}\end{array}$ & $\begin{array}{c}-0.0062^{* *} \\
{[-2.08]}\end{array}$ \\
\hline BSEG & $\begin{array}{c}0.0627^{* *} \\
{[2.36]}\end{array}$ & $\begin{array}{c}0.0627^{* *} \\
{[2.36]}\end{array}$ & $\begin{array}{c}0.0543^{* *} \\
{[2.00]}\end{array}$ & $\begin{array}{c}0.0543^{* *} \\
{[2.00]}\end{array}$ \\
\hline LEV & $\begin{array}{c}-0.1716 \\
{[-0.70]}\end{array}$ & $\begin{array}{c}-0.1716 \\
{[-0.70]}\end{array}$ & $\begin{array}{c}-0.0432 \\
{[-0.18]}\end{array}$ & $\begin{array}{c}-0.0432 \\
{[-0.18]}\end{array}$ \\
\hline OWN & $\begin{array}{c}-0.4229^{*} \\
{[-1.93]}\end{array}$ & $\begin{array}{c}-0.4229^{*} \\
{[-1.93]}\end{array}$ & $\begin{array}{c}-0.1463 \\
{[-0.66]}\end{array}$ & $\begin{array}{l}-0.1463 \\
{[-0.66]}\end{array}$ \\
\hline ROA & $\begin{array}{l}-0.4279 \\
{[-0.53]}\end{array}$ & $\begin{array}{c}-0.4279 \\
{[-0.53]}\end{array}$ & $\begin{array}{l}-0.1482 \\
{[-0.19]}\end{array}$ & $\begin{array}{l}-0.1482 \\
{[-0.19]}\end{array}$ \\
\hline $\mathrm{CFO}$ & $\begin{array}{c}-0.0629 \\
{[-0.13]}\end{array}$ & $\begin{array}{l}-0.0629 \\
{[-0.13]}\end{array}$ & $\begin{array}{c}0.0279 \\
{[0.07]}\end{array}$ & $\begin{array}{c}0.0279 \\
{[0.07]}\end{array}$ \\
\hline Sales_growth & $\begin{array}{l}0.0151 \\
{[0.47]}\end{array}$ & $\begin{array}{c}0.0151 \\
{[0.47]}\end{array}$ & $\begin{array}{l}0.0184 \\
{[0.54]}\end{array}$ & $\begin{array}{l}0.0184 \\
{[0.54]}\end{array}$ \\
\hline$I M R$ & $\begin{array}{c}-0.1185 \\
{[-1.63]}\end{array}$ & $\begin{array}{c}-0.0830^{* *} \\
{[-1.98]}\end{array}$ & $\begin{array}{c}-0.0377 \\
{[-0.58]}\end{array}$ & $\begin{array}{c}-0.1041 \\
{[-1.63]}\end{array}$ \\
\hline Industry dummy & Included & Included & Included & Included \\
\hline Year dummy & Included & Included & Included & Included \\
\hline Intercept & $\begin{array}{c}0.3109^{* *} \\
{[2.53]}\end{array}$ & $\begin{array}{c}0.1589^{* *} \\
{[2.25]}\end{array}$ & $\begin{array}{c}0.2041^{* *} \\
{[2.18]}\end{array}$ & $\begin{array}{c}0.2357^{* * *} \\
{[2.58]}\end{array}$ \\
\hline R-squared & 0.0757 & 0.0802 & 0.0695 & 0.0578 \\
\hline $\mathrm{N}$ & 540 & 540 & 540 & 540 \\
\hline
\end{tabular}




\section{Appendix: Illustrative Examples of AC Report Disclosures}

$\mathrm{CRH} \mathrm{Plc} \mathrm{"Revenue} \mathrm{and} \mathrm{expenses} \mathrm{associated} \mathrm{with} \mathrm{that} \mathrm{contract} \mathrm{should} \mathrm{be} \mathrm{recognised}$ by reference to the stage of completion of the contract activity at the balance sheet date. If it is anticipated that the contract will be loss-making, the expected loss must be recognised immediately."

Admiral Group plc "The Audit Committee considered the provision for claims outstanding comprising provisions for the estimated cost of setting all claims incurred but unpaid as at the balance sheet date, whether reported or not."

Wolseley Plc "The Committee considered the provisions held and settlements made in relation to litigation disputes, potential product liability and environmental claims."

Diageo Plc "AC committee agreed that adequate provision has been made for all material litigation and disputes, based on the currently perceived probability of the outcomes."

Taylor Wimpey Plc "The Committee will continue to focus on ensuring that all the relevant codes and regulations are complied with to ensure that the business is operating in a controlled and managed environment."

SSE Plc "The Group is exposed to the risk of litigation and contractual disputes through the course of its normal operations. The Group needs to consider the level of provision or disclosure in relation to these claims utilising legal advice which is an inherently subjective process."

Schroders Plc "The key judgements used in determining the provisions and contingent liabilities where there is uncertainty over the timing of settlement or amount. The Committee considered and discussed with management and PwC the work performed to confirm the value of the provision, the main areas of uncertainty and the appropriateness of the related disclosures contained within this Annual Report and Accounts."

Rolls-Royce Holding Plc "The amount of revenue and profit recognised during any period requires a significant number of accounting judgements and estimates. Consequently, one of our primary responsibilities is to ensure that the bases for these judgements and estimates are robust."

Pearson Plc "The committee regularly reviews revenue recognition practice and the underlying assumptions and estimates. In addition, the committee has visibility of internal audit findings relating to revenue recognition controls and processes and routinely monitors the views of external auditors on revenue recognition issues." 
Rio Tinto plc "The Committee also focused on the different remediation or closure outcomes which could realistically arise when assessing the adequacy of the provisioning for these obligations. Both involve complex judgments. The Committee focused on the estimates of risk-free discount rates in light of the ongoing impact of fiscal interventions. It also focused on the probability weighting, where appropriate, of the different remediation or closure outcomes which could realistically arise when assessing the adequacy of the provisioning for these obligations. Both involve complex judgments."

Travis Perkins “The Committee considered the Group's provisions for unresolved tax positions. It has received regular updates from management during the year and at the year-end received a paper setting out the latest position based upon the most recent discussions with the Group's advisors and with HMRC. The Committee concluded that the uncertainty justified the provisions held and that the Group's tax position was fairly stated and appropriately provisioned. The Group is currently in discussion with H. M. Revenue and Customs ("HMRC") about the tax treatment of several commercial transactions. The outcome of these discussions is uncertain and so the Group has had to consider what benefits it is appropriate to recognise in the income statement."

Vodafone Group "The timing of revenue recognition, the recognition of revenue on a gross or net basis, the treatment of discounts, incentives and commissions and the accounting for multi-element arrangements are complex areas of accounting."

The Sage Group “The key area of judgement and complexity is the timing of revenue recognition, particularly in relation to the recognition and deferral of revenue on maintenance and support contracts, for instance, where products are bundled. The Group recognises certain provisions and accruals in respect of tax which involves a degree of estimation and uncertainty for certain items whose tax treatment cannot be finally determined until a resolution has been reached with the relevant tax authority." 